\title{
食品の加熱溶出液中のアミノ酸含量に関する研究 (第 3 報) \\ On the Amino Acid Contents in Hot Water Extracts from Food Material (Part 3)
}

\author{
肉類の加熱溶出液中のアミノ酸含量について \\ On the amino acid contents in the hot water extracts from meats \\ (昭 和 39 年 6 月 17 日受 理) \\ 矢吹工 キ 泉 清* \\ (Yuki Yabuki) (Kiyoshi Izumi)
}

The method presented in the previous paper of the authors was applied to the determination of amino acids in hot water extracts from beef, pork, chicken, beef liver, and chicken liver, respectively. Aspartic acid, glutamic acid, glycine, glutamine, histidine, alanine, valine and leucine were relatively abundant in the extracts, and the traces of serine, $\beta$-alanine, proline, asparagine, tyrosine, lysine, threonine, phenylalanine and arginine were also found in the extracts. The actual amino acid contents of animal food extracts were relaltively lower than those of vegetable extracts.

\section{緒言}

第 1 報㧍よび第 2 報においては, 植物性食品中の豆類 および，て荣類について，その加熱調理液中に溶出した 遊離アミノ酸の種類, 含量を報告した。今回は, 動物性 食品中, 豚肉, 牛肝臓, 畄肉, 熖肝荿について, 加熱調 理液中のアミノ酸を検索定量したので，その結果を郝告 ナる。

\section{実験材料および方法}

\section{1. 試 料}

豚肉 $($ ロ - ス $)$

$\left.\begin{array}{l}\text { 鷄肉（ささみ） } \\ \text { 鵎肝 臓 }\end{array}\right\}$ 奈良市肘品

牛 肝 臓大阪市販品

2. 試料の調製

試料の肉扎よび肝臓を $100 \mathrm{~g}$ 科量し， $1000 \mathrm{ml}$ の水で 1 時間湯浴上で煮沸し, 純水で全量を $1000 \mathrm{ml}$ とした。

これを沪過し, 沪液 $100 \mathrm{ml}$ を科取し, 分液ロートに 入れ, エーテル $100 \mathrm{~m} l$ を加光, よく振酒して放置し, 脂肪を分離した沪液をフラスコにとりここの沪液に，再 びェーテル $100 \mathrm{~m} l$ を加え，よく振盜して放置し，分離 した沪液をフラスコにとる。この操作を数回くりかえし て，完全に脂肪を除去した。分液ロートには数回純水を 加党, よく洗涤しながらこの水分もフラスコに5つし

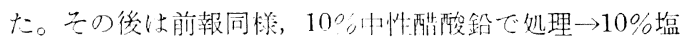

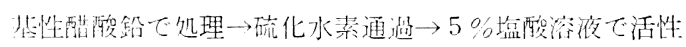

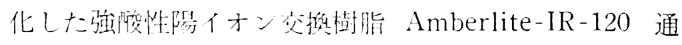

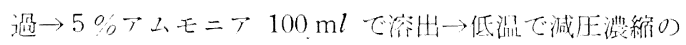

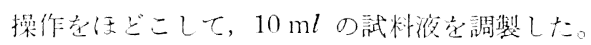

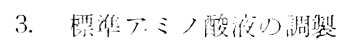

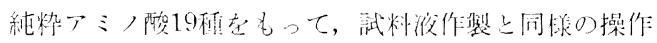

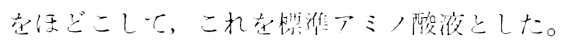

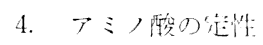

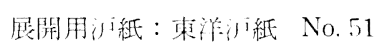

一次元屌開用溶剂：15\%含水フェノール

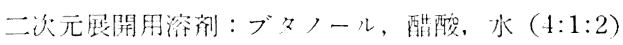

発色剂：0.2\% ニンヒドリン溶液

温 度: 室滥 $\left(19 \sim 21^{\circ} \mathrm{C}\right)$

純粋アミ八酸液，および試料液についての Rf 值によ

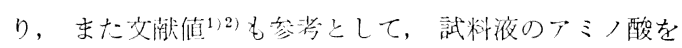
榆索した。その結乐、試料液中のアミノ酸は, 第 $1^{3)}$, 2，3，4，5因の通りでる。

5. アミノ酸の定然

Awapara4) のペーパークロマトグラフィーの方法によ り, 前報同椂に呈色班点抽出を㧍こない, 日立 Photoelectric Photometer で $570 \mathrm{~m} \mu$ の吸光度を測定した。

純粋アミノ酸の標準曲楾(5よって試料液中のアミノ 酸の濃度を求めた。测定結果は第 1,2 表の通りである。 


\section{結果と考察}

第 1 表扣上び第 2 表にみられる通り，肉ロースに比し て，レバーの方が，溶出されるアミノ酸の種類も含量も 多い。また、動物性蛋白 ${ }^{6}$ は，元の種類が優良であり，

第 1 図牛肉の加熱溶出液中に打けるアミノ酸の ペーパークロマトグラム

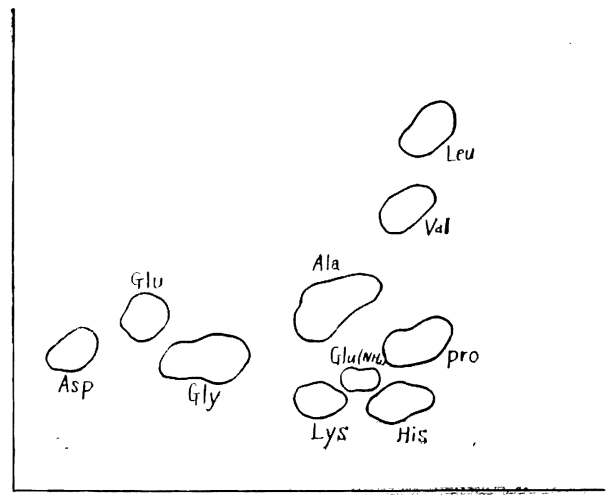

第2 図豚肉の加熱溶出液中におけるアミノ酸の ペーパークロマトグラム

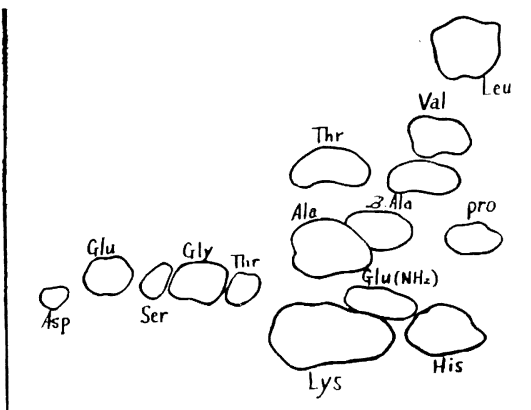

第3 図 舀肉の加熱溶出液中におけるアミノ酸の ペーパークロマトグラム

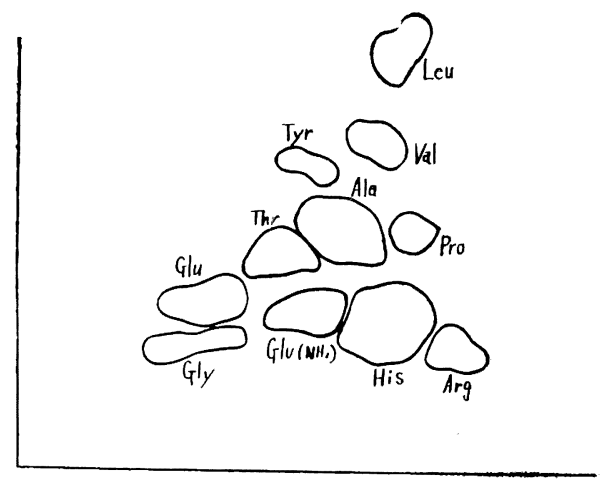


第 17 巻第 4 号

第 1 表 肉類の加熱溶出液中のアミノ酸含量

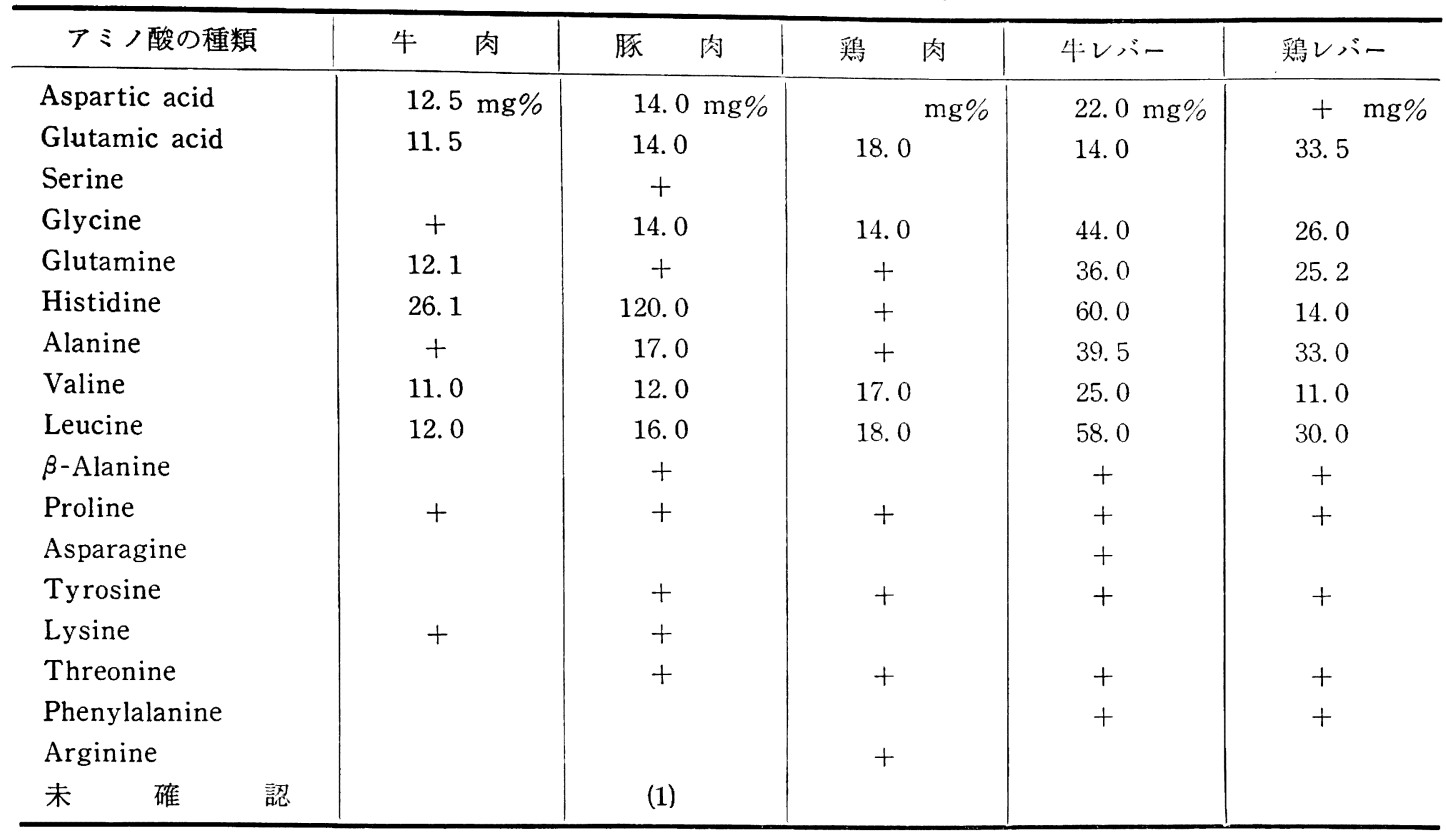

試料 $100 \mathrm{~g}$ を $1000 \mathrm{~m} l$ の水で 1 時間募沸して全量を $1000 \mathrm{~m} l$ としたもの

第 2 表 肉類の加熱溶出液中のアミノ酸含旦

\begin{tabular}{|c|c|c|c|c|c|}
\hline アミノ酸の種類 & 牛肉 & 豚肉 & 㘥肉 & 牛レバー & 蹈レバー \\
\hline Aspartic acid & $\begin{array}{c}\alpha \curlyvee \leqq ノ \mathrm{~N} \\
\mathrm{mg} / 100 \mathrm{~g} \\
19.12\end{array}$ & $\begin{array}{c}\alpha \curlyvee ミ \mathcal{N} \\
\mathrm{mg} / 100 \mathrm{~g} \\
21.42\end{array}$ & $\begin{aligned} & \alpha \text { ア } \mathrm{N} \\
& \mathrm{mg} / \mathrm{N} 00 \mathrm{~g}\end{aligned}$ & $\begin{array}{c}\alpha \text { ア } \mathrm{N} \\
\mathrm{mg} / 100 \mathrm{~g} \\
33.66\end{array}$ & 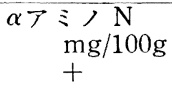 \\
\hline Glutamic acid & 10.93 & 13. 30 & 17. 10 & 13. 30 & 31.83 \\
\hline Glycine & + & 26. 18 & 26.18 & 82.28 & 48.62 \\
\hline Glutamine & 11.62 & + & + & 34.56 & 24. 19 \\
\hline Histidine & 23. 49 & 108.00 & + & 54.00 & 12.60 \\
\hline Alanine & + & 26. 69 & + & 62.02 & 51.81 \\
\hline Valine & 13. 20 & 14. 40 & 20.40 & 30.00 & 13. 20 \\
\hline Leucine & 20.28 & 27.04 & 30.42 & 98.02 & 50.70 \\
\hline Serine & & + & & & \\
\hline$\beta$-Alanine & & + & & + & + \\
\hline Proline & + & + & + & + & + \\
\hline Asparagine & & & & + & \\
\hline Tyrosine & & + & + & + & + \\
\hline Lysine & + & + & & & \\
\hline Threonine & & + & + & + & + \\
\hline Phenylalanine & & & & + & + \\
\hline Arginine & & & + & & \\
\hline 未 確 & & (1) & & & \\
\hline
\end{tabular}

4) J. Awapara : J. Biol. Chem., 178, 113 (1749)

5) 矢吹二キ他：栄塊と食糧, 15, 289 (1962)

6) 岩田久敬: 食品化学, 256, 美蜸堂 (1962)

7) 矢吹二キ他：栄養と食糧，15, 289 (1962)
8）矢吹ユキ他：栄瑟と食糧，16，199（1963）

(奈良学芸大学, *中村栄䔶短期大学) 